\title{
Research on the construction of College Counselors Team under the perspective of internationalization Jie Ren
}

\author{
ChongQing Technology and Business Institute 400052
}

\begin{abstract}
Keywords: Universities and colleges, counselor, team construction, internationalization,
\end{abstract}
\begin{abstract}
Since twenty-first Century, with the rapid development of information technology and the increasingly close economic and cultural exchanges , the internationalization will also be a trend which cannot be halted.However, the present situation of the management of College Counselors in domestic is not optimistic.Therefore, it is essential to promote the construction of the college counselor team under the perspective of internationalization.

Based on the analysis of the present situation of counselor team in Colleges and universities, this paper discusses the necessity of strengthening the of internationalization college counselors team.And, based on our national conditions, people-oriented, this paper presents many new paths to strengthen the team construction of counselors.

Through reference and absorption of advanced foreign student affairs work experience, overall planning, this paper actively explore the road of internationalization of university counselor team construction.

Under the background of economic globalization, internationalization has become an inevitable trend of the development of education with the rapid development of information technology and the increasingly close economic and cultural exchanges.

As an important part of the construction of colleges and universities, college counselors also need to solve the related issues of the education internationalization.Therefore, this paper discusses the construction of college counselor team under the international perspective, the necessity to strengthen the College Counselor Team International and the new paths to improve the college Counselors Team.
\end{abstract}

\section{Status quo of the management of College Counselors}

At present, the status quo of college counselors is not optimistic, and many education experts conducted a series of profound investigation, analysis and research on College counselors.The questionnaire survey results show that the college counselors is outnumbered , the title promotion has so few opportunities, and the main problems is the lack of relevant solutions.

Gan Xu put forward that the main problems of the construction of college counselors team is the vacancies serious of counselors,the instability of the team, the competence of counselors does not meet the need of the reform of colleges and Universities, a lot of affairs weakened function, the excessive transactional work ,lag of the management system,the low salary,etc..

Through the visit and investigation, Zhang Bowei classified on the the construction of college counselors team problems, mainly summarized as follows.Firstly, the counselors team is unstable.Their short working period, the low degree of specialization, and lack of a sense of belonging are the main reason for the instability of the counselor team.Secondly, Because of the age, quantity, degree, professional, professional title structure is unreasonable,the overall quality of the contingent of counselors is low.Thirdly, Because the positioning, role of multi, heavy workload, complex objects, assessment difficult and other reasons, the counselors social identity is low, and more prone to occupation burnout.Finally, Due to less income, low salary, promotion, psychological pressure, difficult work life much wait for a reason, counselors can not concentrate on their work.

A lot of research results can be summarized in today's college counselors problems are mainly the following points. 


\subsection{Counselors workload and the task is very onerous}

The contemporary college counselors work tasks and contents have three main respect.

First, the ideological and political education is the primary task of College counselors.The basic content of Ideological and political education includes,the patriotism education of Marx Lenin doctrine, Mao Zedong thought, Deng Xiaoping theory, the party's line, the policy of the party, the party's policy etc.And the ideal and belief of World outlook, outlook on life, values, etc.

The second is the class management, including the behavior of college students and students' construction Standardization management.Management of college students' behavior specification is the main task of University counselors, its main content conclude the schedule management of students,class leave and attendance, students archives material, yearly summary, appraisal, credit management,security,rewards and punishment management.The main contents of students' construction is the construction of Party organization,construction of the class committee and student community, student cadres, spiritual civilization construction, class work system. The basic requirements for students in class construction from the basics,In order to strengthen the aim and pertinence.

Finally, the instructor needs to provide advisory services.In recent years, influenced by the developed country university student affairs in theory and practice, providing professional counseling services for students has become an important duty of counselors.

1.2 Serious shortage of counselors result in unable to meet the needs of the enrollment expansion

Since the beginning of 1999, China began to expand the ordinary university college enrollment in order to solve the economic and employment issues.The number of university students in our country leads to a sharp increase, but the counselor quantity is increased, resulting in excessive burden of Counselors.According to the statistics,in China's colleges and universities, only $14.3 \%$ school counselors and students in the proportion of more than 1:200, and The number of counselors and students have serious imbalance.The scale variation trends of China's college students and counselors over the years are shown in Chart1.

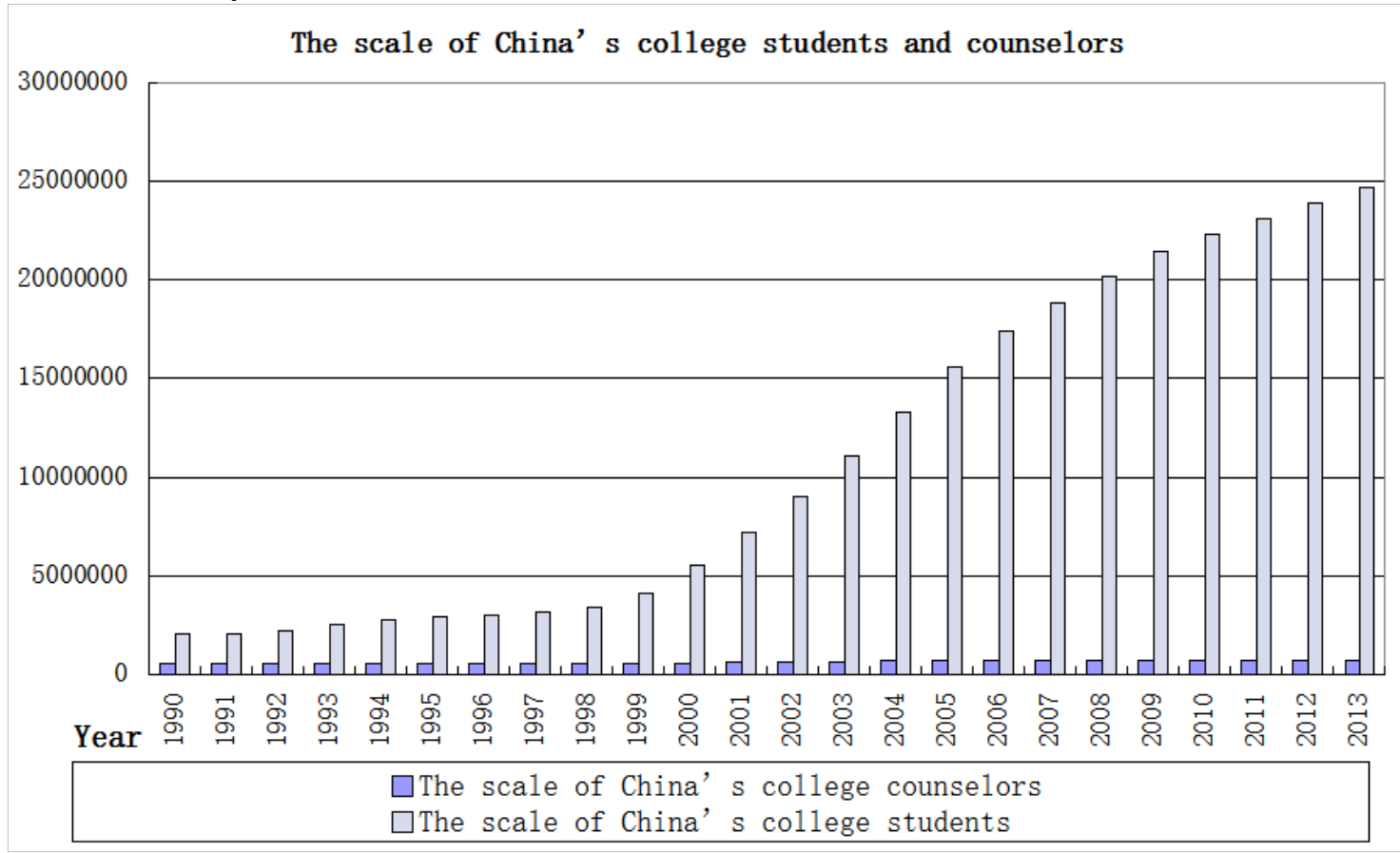

Pic 1:The scale variation trends of China's college students and counselors

1.3 The overall quality of counselors is low, so can not adapt to the change of situation

The main reason for the low quality of counselors has two aspects. On the one hand, China started to set up the political system of College Counselors from 1953.More than half a century, large numbers of counselors have made great contribution to the ideological and political education of higher education and University students.However, in today's international development trends, especially with the cloud era, the experience of college students increasingly rich.The thoughts of 
college students is becoming more complex, so the students work becomes more difficult, leading to the counselors are difficult to catch up the pace of students thinking.

On the other hand, almost all the current college counselors are from graduates or recruitment, few from other channel selection.Location selection of school counselors include young,energetic, ready to work overtime,and etc..Because of this, the counselor general lack of life experience and work experience,lead to the low efficiency and the improper method.From the academic structure, a lot of college counselors mainly with college, less of graduate students ,more less of Master graduate student, so appeared the phenomenon of undergraduate management undergraduate.

\section{The necessity to strengthen international of the College Counselor Team}

The twenty-first Century is the era of information and technology, talent is the most important.Higher school's main function is to engage in scientific research and social service, training specialized personnel.For the counselors position, the Ministry of education thought that counselors are the backbone of Ideological and political education of college students, and shall organize the college students' daily ideological and political education management, and guide the healthy growth of College students.Therefore, keeping pace with the times, strengthen the internationalization of University Counselors should be imperative.

2.1 The internationalization of the construction is the inevitable requirement of the internationalization of Higher Education

Today's Chinese University, internationalization has profound influence all their ideas of education, discipline construction, curriculum setting, teaching staff construction, personnel training, student work.

For example: Peking University has carried out cooperation with 378 universities and research institutions in more than 50 countries and regions in the world.The construction of a number of high level university with Chinese characteristics and the world first-class has become an important strategy for the development of China's higher education.As an important force to cultivate talents, ,college counselors must comply with the international trend of development, closely follow the international trend, accelerate the pace of internationalization, correctly understand and accurate analysis of the new situation and new problems, learn the advanced ideas of students work and advanced method.

2.2 The international of college counselor team is an urgent need for College Students

The Internet allows the internationalization of college students view.The Internet connects the world,and provides the opportunities to the vast number of students of international vision .In the international arena,the China's college students' willing to show talent is becoming increasingly intense, and the international atmosphere also be increasingly strong .

Taking Peking University as an example, there are nearly 2000 students studying abroad exchanges Sino foreign joint training each year, more than 1000 students attend. Internationalization has become the important content of the students' learning. Facing the trend of internationalization of higher education, especially with the students, international experience and rich international vision of the upstream open and internationalization requirements, University Counseling team must seriously study the characteristics of students and the development of talent demand, and constantly improve the work idea, methods and ways of college students, to meet the needs of the development of internationalization.

2.3 The internationalization is the specific requirement of student work

More and more colleges and Universities active building the cooperative communication platform with other countries.Colleges and universities in China learn the advanced experience from other countries, and continuously improve the scientific level of the students.

According to statistics, at present, more than 700 colleges and universities in China and other countries have established the system of exchange students .Some colleges and universities provide the professional services and integration in learning first-class domestic and international, established the student affairs development center, and refers to the student quality evaluation system.This requires counselors develop their international vision, enhance the ability to quickly 
adapt to the trend of internationalization, and improve the students work system and method.

\section{New path to strengthen the construction of counselor team}

3.1 Based on long-term development,Establish an accurate international team

First, universities should expand the international multi view and innovation of the ideas of the construction of counselor team. The construction of college counselors team should learn the theory and practice from different countries.In the process of selection and comparison, they should grasp the leading power and initiative. The mode of Western college students work team is not the same, such as almost all colleges and universities in America are independently set the student affairs organization, and has a group of professional, occupation, student work team. While in France, there is an management system of highly social, named a "National University affairs center" and 28 "region of the affairs of the University Centers", responsible for the management of student work team.In Britain, they centralized management and decentralized management combination, build the student affairs office and the College Tutor school level combination.We're betting to get good choice, takes its essence, to innovative the ideas of the construction of political instructor team .

Secondly, we should absorb and draw lessons from the international excellent resources, to improve the platform of college counselors team.Based on developing international multiple perspectives, we should actively absorb and the introduction of international advanced experience.The number and variety of American college students work more professional association, association undertakes improvement of coagulation and service, norms and guidance, decision and consultation, exchange and research functions, and continuously improve the student worker specialization degree and professional level.The affairs of the University Center in France have high level in work team occupation, so the degree of specialization is strong.China's colleges and universities should take active measures to promote the professional counselor team, and constantly improve the occupation standard of behavior, making the college counselors received good professional training.From the perspective of professional occupation, such as expanding , the construction of college counselors team channel refer to the integration of international excellent resources, improve the counselors, learning platform occupation platform and develop the platform.

Third, strengthen the international development ability, improve the coaching and building team system.Based on absorption, we should make sure the reference and integration of international excellent resources, also guide the counselors strengthen consciousness in the process of internationalization, adhering to the socialist core value system of Marxism, overall good domestic and international relations, professional and systematic relations, characteristics and normalization of relations, dominance and diversity relations.In learning from western experience, both to be modest and prudent, we constantly improve the counselor employment mechanism, management mechanism, evaluation mechanism and training mechanism, establish a counselor team to meet the needs of students and school .

\subsection{Overall planning, actively explore the internationalization}

First of all, Enhancing the interaction in international exchanges, the universities should enhance the system of the construction of College Counselors Team.Universities should actively promote the world elite organization counselors on the spot, in the investigation process of various interacting with scene type, experience type, the more sober understanding, accurate understanding of the differences and disparities.In recent years, More and more teachers in Colleges and universities began to exchange experience with foreign universities .Peking University, Tsinghua University and other domestic first-class university started to select part of counselors to some universities every year.Shanghai International Studies University organizes all counselors to join in many Canadian trainee.At the same time, Huazhong University of Science and Technology held the International Symposium on college student affairs,Asia Pacific Association of student affairs, representative of French, Australia and other countries, domestic colleges and universities attended the meeting. 
Secondly, Universities and colleges should be in the study, comparison, reference scientific to strengthen the construction of College Counselors Team.College counselors should be the combination of theory and practice to find out their own development path of internationalization, and use foreign advanced theory to contact and guide the domestic practice. The University also can take home to the test of practice the theory of foreign countries, from a multi dimension comparison test, so as to enhance the international open and scientific.Such as the Peking University formed a group of results, based on the training practice in the University of Pennsylvania, Johns Hopkins University, Princeton University America school.

Finally,colleges and universities should sum up the experience in practice, so as to enhance the effectiveness of the counselors construction.On the basis of the research, the counselor team building internationalization also should straighten out the multiple relations in practice, continuous integration of foreign different universities advantages.Colleges and universities should concise experience, at the same time, Grasp the right direction and measure of internationalization, so as to improve the efficiency and effectiveness of international. Colleges and universities should also guide the counselors to advance experience,to enhance the work of the initiative and subjectivity, thus enhancing the pertinence and effectiveness of work.In America University of Pennsylvania some of the world first-class university students work,Professional and systematic complement each other,Globalization and localization complement each other,The organic combination of standardization and specialization formed a benign interaction,but this is very rare in domestic colleges and universities.In learning and absorbing foreign advanced experience, the management of colleges and universities must consider the situation of the domestic components and the school situation at the same time,and rganic combination of the traditional humanistic care,Outstanding achievements and the construction of Harmonious Campus,beyond the ascension in practice.

\section{References}

[1] Paul Hager.Current Theories of Workplace Learning: A Critical Assessment.International Handbook of Educational Policy .2005.

[2] Laura A.Dean.CAS Professional Standards for Higher Education.2006.

[3] S.Bolhuis.Learning in the Workplace: New Theory and Practice in TeacherEducation.Work-Related Learning .2006.

[4]Clare Sheam.A new student suppoa and guidance system fit for the21st century.Perspectives on Personal Tutoring in Mass Higher Education.Supporting Diverse Students--the first national confemnce on Personal Tutoring .2005.

[5]ACPA.Student Learning Imperative:Implication for Student Affairs. 2008. 